polysaccharide Streptococcus pneumoniae vaccine. Rheumatology (Oxford) 2012;51:761-762.

8. Morita R, Ikegami Y, Furutama J, Watanabe M, Hashimoto K, Yamasaki M, Arita K. A suspected case of Behcet's disease with severe side effect to pneumococcal vaccination. Hiroshimaigaku 2014;67:695-698.
9. Kawasaki $Y$, Hayashi $K$, Ishikawa T, Onishi T, Tada $Y$, Watanabe S. A case of cellulitis-like reaction after pneumococcal vaccination. Hifubyoshinryo 2017;39:471-474

๑Copyright 2021 by Turkish Society of Hematology

Turkish Journal of Hematology, Published by Galenos Publishing House

\title{
Post-Chemotherapy Foamy Histiocytes in Bone Marrow Aspiration of a Child with Acute Lymphoblastic Leukemia
}

\author{
Akut Lenfoblastik Lösemili Bir Çocuğun Kemik Illiği Aspirasyonunda Kemoterapi Sonrası \\ Köpüklü Histiyositler
}

\author{
(D) Moeinadin Safavi1, (D) Zohreh Nozarian², (D) Farzad Kompani³ \\ ${ }^{1}$ Tehran, Iran \\ 2 Tehran University of Medical Sciences, Tehran, Iran \\ ${ }^{3}$ Tehran University of Medical Sciences, Division of Hematology and Oncology, Children's Medical Center, Pediatrics Center of Excellence, \\ Tehran, Iran
}

\section{To the Editor,}

Foamy histiocytes are usual in a variety of disorders such as metabolic and/or lysosomal storage disorders as well as prolonged total parenteral nutrition $[1,2]$. Post-chemotherapy foamy histiocytes have been reported only twice in bone marrow aspiration (BMA) smears according to our investigation, in one case of acute myeloid leukemia and one case of metastatic adenocarcinoma of the prostate $[3,4]$. Here we report a new case of post-chemotherapy foamy histiocytes in BMA smears.

An 8-year-old girl presented with bone pain mostly in the left pelvis and lower limbs, fever, and weight loss for 2 weeks. Paleness and lymphadenopathy in the left submandibular and supraclavicular regions were found on physical examination. No other abnormal findings or hepatosplenomegaly were seen according to the general physical examination, abdominal sonography, or chest $\mathrm{X}$-ray. Initial laboratory data showed a low hemoglobin level of $9.5 \mathrm{~g} / \mathrm{dL}$ (reference range: 11-16 $\mathrm{g} / \mathrm{dL}$ ) and platelet count of

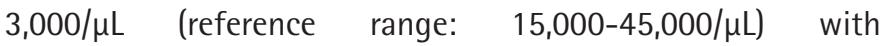
a leukocyte count of $5,500 / \mu \mathrm{L}$ (reference range: $4,000-10,000 / \mu \mathrm{L})$. Other prominent laboratory findings were elevated erythrocyte sedimentation rate of $110 \mathrm{~mm} / \mathrm{h}$ (reference range: $0-10 \mathrm{~mm} / \mathrm{h}$ ) and lactate dehydrogenase of 1,118 IU/L (reference range: $420-750 \mathrm{IU} / \mathrm{L}$ ).
BMA was performed and showed more than 90\% immature large cells with high nuclear to cytoplasm ratio and fine chromatin. In the flow cytometry of the BMA, these cells were positive for CD34, HLA-DR, TdT, CD10, CD19, and CD22 and were negative for CD3, CD20, CD117, and MP0. These findings confirmed the diagnosis of pre-B acute lymphoblastic leukemia NOS (pre-B ALL, NOS). Molecular analysis was negative for $\mathrm{t}(9 ; 22) / \mathrm{BCR}-\mathrm{ABL} 1, \mathrm{t}(12 ; 21) /$ ETV6-RUNX1， $\mathrm{t}(1 ; 19) / T C F 3-P B X 1$, and $\mathrm{t}(4 ; 11) /$ KMT2A-AFF1.

Standard chemotherapy was started according to the BerlinFrankfurt-Munster protocol including methylprednisolone at $60 \mathrm{mg} / \mathrm{m}^{2} /$ day, intravenous vincristine at $1.5 \mathrm{mg} / \mathrm{m}^{2} /$ day, intravenous daunomycin at $25 \mathrm{mg} / \mathrm{m}^{2} /$ day, intramuscular L-asparaginase at 6,000 units $/ \mathrm{m}^{2} /$ day thrice weekly for 9 doses, and an intrathecal injection of cytosine arabinoside (Ara C; $30 \mathrm{mg}$ ), methotrexate $(12.5 \mathrm{mg})$, and hydrocortisone (12.5 mg) [5].

BMA was performed 3 weeks later for evaluation of the early response to treatment after induction chemotherapy. Smears showed multiple foamy histiocytes (Figures $1 \mathrm{~A}$ and $1 \mathrm{~B}$ ) and initial remission according to BMA cytology and immunophenotyping. In these histiocytes, there were many variably sized large vacuoles, which differed from sea-blue macrophages. No 

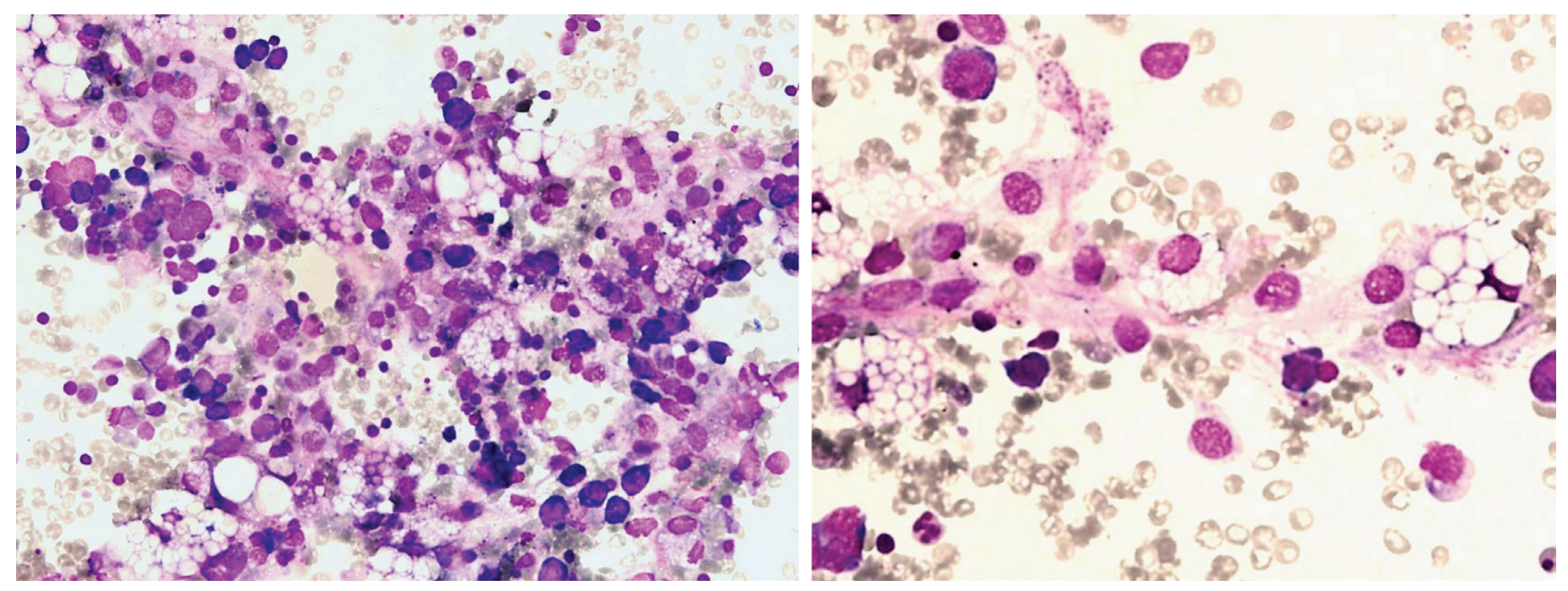

Figure 1. Smears showed multiple foamy histiocytes (A, B).

evidence of hemophagocytosis was observed. Unfortunately, metabolic screening had not been performed at birth for this patient. As she had no past medical history of any metabolic or lysosomal storage diseases, developmental delay, organomegaly, and/or metabolic crisis, there was no medical indication for evaluation of metabolic diseases. Interestingly, the foamy histiocytes disappeared in the subsequent BMA smears, which was taken as evidence against a metabolic disorder.

Post-chemotherapy foamy histiocytes were reported in only one previous case of acute myeloid leukemia 2 weeks after chemotherapy. That report suggested that the foamy histiocytes were related to degradation products of blasts phagocytized by the histiocytes. This finding might also be an idiosyncratic response to the chemotherapy [3]. In conclusion, a history of intensive chemotherapy should be considered in the list of differential diagnoses of foamy histiocytes in bone marrow specimens.

Keywords: Acute lymphoblastic leukemia, Chemotherapy, Foamy macrophage

Anahtar Sözcükler: Akut lenfoblastik lösemi, Kemoterapi, Köpüksü makrofaj

\section{Ethics}

Informed Consent: Informed consent was obtained from the patient's guardian in Persian.

\section{Authorship Contributions}

Analysis or Interpretation: M.S., Z.N., F.K.; Literature Search: M.S., Z.N., F.K.; Writing: M.S., Z.N., F.K.

Conflict of Interest: No conflict of interest was declared by the authors.

Financial Disclosure: The authors declared that this study received no financial support.

\section{References}

1. Bigogne C, Leturneau A, Vahedi K, Rio B, Messing B, Molina T, Audouin J, Diebold J. Sea blue histiocyte syndrome in bone marrow secondary to total parental nutrition. Leuk Lymphoma 1998;28:523-529.

2. Machaczka M, Klimkowska M, Regenthal S, Hagglud H. Gauche disease with foamy transformed macrophages and erythrophagocytic activity. J Inherit Metab Dis 2011;34:233-235.

3. Tavil B, Bozkaya I, Yarali N, Tunc B. Foamy histiocytes in a child with acute myeloid leukemia. Pediatr Hematol Oncol 2012;34:320-321.

4. Yigit N, Turbiner Geyer J. Bone marrow metastasis of prostatic adenocarcinoma with post-treatment foamy-like changes: a diagnostic pitfall. Can Urol Assoc J 2014;8:E941-943.

5. Chang JE, Medlin SC, Kahl BS, Longo WL, Williams EC, Lionberger J, Kim K, Kim J, Esterberg E, Juckett MB. Augmented and standard Berlin-FrankfurtMunster chemotherapy for treatment of adult acute lymphoblastic leukemia. Leuk Lymphoma 2008;49:2298-2307.

๑Copyright 2021 by Turkish Society of Hematology

Turkish Journal of Hematology, Published by Galenos Publishing House

\begin{tabular}{|c|c|c|}
\hline 口:14 & $\begin{array}{l}\text { Address for Correspondence/Yazışma Adresi: Zohreh Nozarian, M.D., Tehran University of Medical Sciences, } \\
\text { Tehran, Iran } \\
\text { Phone : +989121715317 } \\
\text { E-mail : drznozarian@amail.com ORCID: orcid.org/0000-0002-2004-4479 }\end{array}$ & $\begin{array}{r}\text { Received/Geliş tarihi: November 11, } 2020 \\
\text { Accepted/Kabul tarihi: January 14, } 2021\end{array}$ \\
\hline
\end{tabular}

